\title{
ANALYSIS OF INVESTOR SENTIMENT IMPACT IN INDONESIA COMPOSITE STOCK PRICE INDEX RETURN VOLATILITY
}

\author{
Rum Puspita Widhiarti*1), Lukytawati Anggraeni**), and Syamsul Hidayat Pasaribu**) \\ *) School of Business, Bogor Agricultural University \\ Jl. Pajajaran, Bogor 16151 \\ **) Department of Economics, Faculty of Economics and Management, Bogor Agriculture University \\ Jl. Agatis, Campus IPB Dramaga, Bogor 16680
}

\begin{abstract}
The Composite Stock Price Index (IHSG) is an index used as an indicator of stock price movements on Indonesia Stock Exchange and reference of capital market activities. Stock securities have high risk because they do not have maturity such as bonds so volatility is one of the important things in stock investment. Investor sentiment is one of many external factors that affecting stocks volatility. Investor sentiment is one of behavioral finance assumptions which may cause systematic risk with noise so it affects stocks volatility. Therefore it is necessary to analyze the development of investor sentiment and its impact on IHSG volatility. This study used Business Tendency Index as investor sentiment proxy and monthly IHSG. Bank Indonesia Certificates is used to get excess return. GJR-GARCH method is used in this study along the periode from January 2001 to December 2015. The results showed that there is significant effect of investor sentiment on excess return. As investors are optimistic, the uncertainty in stock market will increase while IHSG volatility will increase as the average investor is pessimistic. There is noticeable leverage effect in the presence of negative shocks resulting in higher conditional variance changes compared to positive shocks on the same magnitude.
\end{abstract}

Keywords: volatility, investor sentiment, GJR-GARCH, behavioral finance, IHSG

\begin{abstract}
Abstrak: Indeks Harga Saham Gabungan (IHSG) merupakan indeks yang digunakan sebagai indikator pergerakan harga saham di Bursa Efek Indonesia dan sebagai acuan kegiatan di pasar modal. Sekuritas saham memiliki resiko yang cukup tinggi karena tidak mempunyai jatuh tempo seperti obligasi sehingga volatilitas merupakan salah satu hal yang penting dalam kegiatan investasi saham. Volatilitas saham dapat dipengaruhi oleh berbagai faktor eksternal, salah satunya yakni sentimen investor. Sentimen investor merupakan salah satu asumsi dari perilaku keuangan yang dapat menimbulkan risiko sistematis dengan adanya noise yang akan berpengaruh kepada volatilitas saham. Oleh karena itu perlu dilakukan penelitian menganalisis perkembangan dari sentimen investor dan dampaknya terhadap volatilitas IHSG. Penelitian ini menggunakan Indeks Tendensi Bisnis sebagai proksi dari sentimen investor dan data bulanan IHSG. Data Sertifikat Bank Indonesia digunakan untuk mendapatkan excess return. Metode GJRGARCH digunakan pada penelitian ini dengan periode dari bulan Januari 2001 hingga bulan Desember 2015. Hasil penelitian menunjukkan bahwa terdapat pengaruh yang signifikan dari sentimen investor terhadap excess return. Saat investor optimis, maka ketidakpastian dalam pasar saham akan meningkat sedangkan volatilitas IHSG akan meningkat saat investor bersifat pesimis. Adanya efek leverage yang terlihat apabila terdapat guncangan negatif akan menghasilkan besar perubahan conditional variance lebih tinggi dibandingkan dengan guncangan positif pada magnitude yang sama.
\end{abstract}

Kata kunci: volatilitas, sentimen investor, GJR-GARCH, perilaku keuangan, IHSG

\footnotetext{
${ }^{1}$ Corresponding author:

Email: arum.pw@gmail.com
} 


\section{INTRODUCTION}

Macroeconomic is not the only factor which can affect stocks market volatility but investor sentiment can also affect the volatility of the market as proposed by Brown and Cliff (2004). In an inefficient market such as Indonesia (Hoque et al. 2007; Kim and Shamsuddin 2008), investor sentiment is a variable that forms stock market prices, which is investor's confidence about future cash flows not supported by fundamental information (Morck et al. 1990).

The emergence of investor sentiment derived of the term noise which first introduced by Black (1986). Furthermore, there are several behavioral models developed by other researchers such as De Long et al. (1990) also Campbell and Kyle (1993) who explained noise traders in determining the stock price. Irrational investors who act based on noise can cause risk systematic (Brown and Cliff, 2004 ). When noise traders who affected prices and the signals from noise was sentiment, then that risk would become volatility. It indicates a relationship between investors sentiment with volatility.

The emergence of financial behavior caused by several market crashs such as Black Thursday in 1986 and Black Monday in 1987 in USA, shows that emotions can overcome rational investors. It was not consorted to the classic financial theory which stated that investor's behavior is rational in decision-making for investment activities. The existence of those anomalies supports the financial researchers who studied behavioral finance that arise due to anomaly in financial and stock market which cannot be explained by traditional finance. According to Uygur and Tas (2014) behavioral finance is a new approach in financial markets that has emerged as a response to the complications faced by the traditional finance theory. There are two assumptions of financial behavior, limit to arbitrage and investors sentiments, which is the theory of how investors form beliefs and value (Thaler, 1999). The existence of market sentiment contradicts with Efficient Market Hypothesis $(\mathrm{EMH})$ theory, where market reflects all informations include past information, public information, and private information.

In investing, especially in stocks investment, there are two important things namely the rate of return or yield (return) and risk. Stocks do not have time maturities like bonds, so stocks are very risky securities (Manurung and Manurung, 2009). The other less important components is volatility of stock return where the volatility as a description of the low and high level of risk as well as stock returns. Saad and Siagian (2011) stated that the components of stocks market value (price) is consisted of asset in place value plus growth opportunity value. In addition, other components that also form the stock market value (price) is investor sentiment, which is investor's confidence about future cash flow expectations of company that is not supported by accounting information (fundamentals). If investor sentiment is followed by a substantial change of demand on the company's stock then mispricing occurred. The result of investor sentiment is investor funds flow in securities that do not provide maximum return at certain risk level (Puspitaningtyas, 2013).

Indonesia is currently one of the emerging countries and still contriving on country development, where investment activity is one of the attempts undertaken in the country's economy improvement. The Composite Stock Price Index (IHSG) is used by investors to see the capital market development and become a consideration in making investment decisions. The Business Tendency Index (ITB) is an indicator that provides information on the state of business and the economy in the short term (quarterly) and can be used to assess the business situation in the current quarter and forecasts for the next three months (BPS, 2013). The value of ITB and IHSG return from 2001 until 2015 presented in Figure 1.

Based on Figure 1, there was a significant decrease of ITB value during the study period. At early 2003, also early and end of 2005 there were fuel oil (BBM) price increments so that investors are pessimistic with Indonesia business conditions which is indicated by quite low value of ITB. There is also decrease in IHSG return and the value is quite low at the early 2003 . The same thing happened at early and end of 2005 where IHSG return were declined even reached negative value in October 2005. There was also a drastic decrease in IHSG return in 2008. The IHSG return values were negative from June 2008 to February 2009 except in December 2008. The negative value of IHSG return in October 2008 were the lowest during research period. This is due to global financial crisis or known as Subprime Mortgage. In that period it has an impact on the Indonesian economy. The ITB value also decreased 
during that period which was seen in low ITB value below 100 in early 2009 but there was a slow increase later.

Some studies on investor sentiment has been done both globally and regionally. Study by Lee et al. (2002) suggest that sentiment movements have a negative effect on market volatility, while in Sayim (2012) and Tourani-Rad et al. (2008) investor sentiment is influential and has a significant effect on stock volatility. There are several variables that can be used as a proxy of investor sentiment. The Brazilian consumer sentiment index is used by Calafiore (2010) while Lovell (2013) used survey data from futures market uninformed and institutional investors as a proxy of investor sentiment. Johnk (2012), Huerta et al. (2016) used investor sentiment proxy in the form of American Association of Individual Investors (AAII) and Investor Intelligence (II). Lee et al. (2002), Brown and Cliff, 2004) used II as a proxy of investor sentiment, while Verma and Verma (2006), Sayim et al. (2013) uses AAII as a proxy of investor sentiment. The Customer Confidence Index (CCI) is used by Yu et al. (2014) as a proxy of investor sentiment. Tourani-Rad et al. (2008) used daily aggregate mutual fund flows of domestic US equity funds.

The research of investor sentiment effect in Indonesia stock market has been done by Kencana (2015) using mutual fund flow as a proxy of investor sentiment. This shows the need for research of investor sentiment effect using other variables for investor sentiment's proxy. Based on problem formulation described above, the aim of this study is to analyze investor sentiment development in Indonesian stock market, as well its impact on volatility return in Indonesian stock market.
The scope of this study is to analyze investor sentiment development and its impact on IHSG for 15 years from January 2001 to December 2015. This study used GJR GARCH method and Business Tendency Index (ITB) as a proxy of investor sentiment because ITB is considered to represent investors in assessing the business condition in Indonesia. This study examined the hypothesis of whether investor sentiment does not have any impacts on IHSG volatility. ITB utilization will show its impact on IHSG volatility if there was asymmetric volatility when there were positive and negative sentiment.

\section{METHODS}

The data used for this research is time series data which was monthly data start from January 2001 until December 2015. The software used in this research is Eviews 9.0. The data used were the closing prices of IHSG, Bank Indonesia Certificates (SBI), and Business Tendency Index (ITB). ITB value were quarterly so Eviews was used to do interpolation in order to get monthly data. The data used in the study is presented in Table 1.

\section{Return Calculation}

IHSG closing price data is processed into return and calculated using the method adopted from Sadaqat and Butt (2014) as follows:

$$
r_{t}=P_{t} /\left(P_{t}-P_{t-1}\right)
$$

Where: $r_{t}$ (IHSG stock Return in t period (percentage)); $P_{t}$ (IHSG closing price in t period (rupiah)); $P_{t-1}$ (IHSG closing price in one period before $t$ (rupiah)).

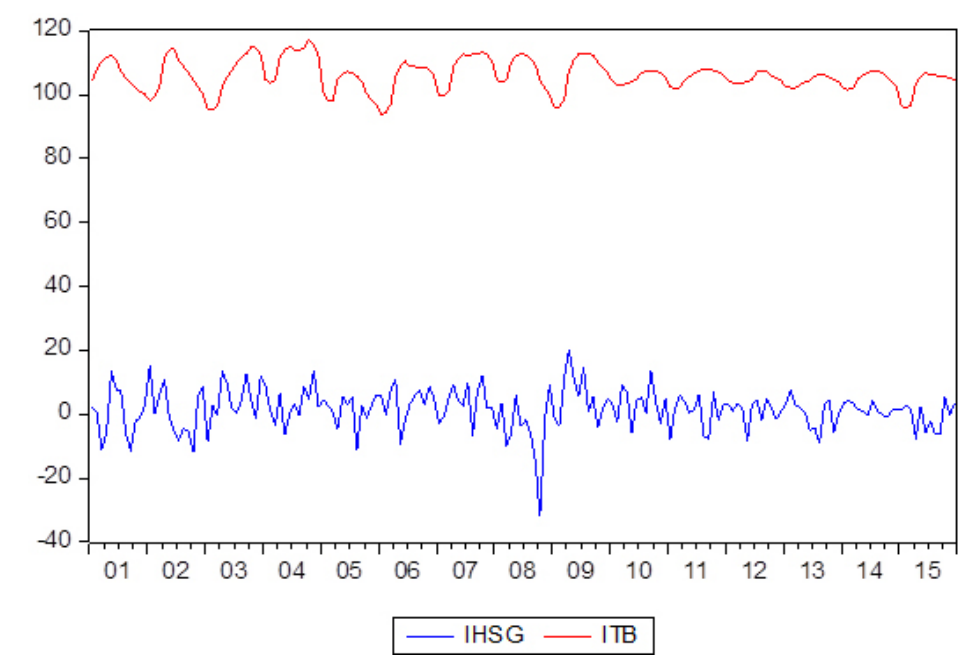

Figure 1. ITB Value and IHSG Return from 2001 to 2015 
Table 1. Data types and sources

\begin{tabular}{llll}
\hline Variables & Units & Data Sources & References \\
\hline IHSG Closing Price & Rupiah & Yahoo Finance & (Uygur dan Tas 2014) \\
Bank Indonesia Certificates & Percentage & Bank Indonesia & (Sadaqat dan Butt 2014) \\
Business Tendency Index & Index & BPS & (BPS, 2013) \\
\hline
\end{tabular}

\section{ARCH-GARCH Model}

Variance (or standard deviation) is often used as a measure of risk in risk management. Engle (1982) introduced the Autoregressive Conditional Heteroscedasticity (ARCH) model to time series financial model which show the time difference to conditional variance. The $\mathrm{ARCH}$ model and its variations are able to represent as a model of return and risk simultaneously by using time series data (Ender 2004). The General ARCH (GARCH) model developed by Bollerslev (1986) is another popular model for estimating stochastic volatility. This model is widely used in various branches of econometrics, especially in financial analysis of time series. In ARCH and GARCH models, heteroscedasticity is considered a variance to be modeled and it is not as a constraint. For investors in financial markets, variance is important if investors want to use the model to earn the highest return on income for a certain risk.

This research used GJR-GARCH which is variation of ARCH model. The GJR-GARCH model was proposed by Glosten et al. (1993) is an Asymmetric GARCH (AGARCH) model that accommodates the asymmetric response of stock returns to positive shocks or negative shocks. Positive or negative shocks are assumed to be positive or negative information changes. Proxy of investor sentiment used in this research is ITB, while risk free rate variable used in this study is Bank Indonesia Certificate (SBI). The aim of using risk free rate is to get excess return. The GJR-GARCH model used in this study is adopted from Sadaqat and Butt (2014) is as follows:

$$
\begin{aligned}
\mathrm{r}_{\mathrm{t}}-\mathrm{r}_{\mathrm{f}}= & \alpha_{0}+\alpha_{1} \log \left(\sigma_{\mathrm{it}}\right)^{2}+\alpha_{2} \mathrm{SI}_{\mathrm{t}}+\alpha_{3} \mathrm{SI}_{\mathrm{t}-1}+\theta_{\mathrm{i}} \sum_{\mathrm{i}=\mathrm{t}-1}^{\mathrm{n}} \mathrm{r}_{\mathrm{t}-1}-\mathrm{r}_{\mathrm{f}-1}+\varepsilon_{\mathrm{it}} \\
\varepsilon_{\mathrm{it}}= & \vartheta_{\mathrm{t}} \sigma_{\mathrm{t}} \quad \vartheta_{\mathrm{t}} \sim \mathrm{N}(0,1) \\
\sigma_{\mathrm{it}}^{2}= & \beta_{0}+\lambda_{\mathrm{i}} \sum_{\mathrm{j}=1}^{\mathrm{p}} \varepsilon_{\mathrm{t}-1}^{2}+\omega_{\mathrm{i}} \varepsilon_{\mathrm{it}-1}^{2} \mathrm{I}_{\mathrm{t}-1}+\gamma_{\mathrm{i}} \sum_{\mathrm{k}=1}^{\mathrm{q}} \sigma_{\mathrm{t}-1}^{2}+\beta_{1} \mathrm{SI}_{\mathrm{t}-1} * \mathrm{D}_{\mathrm{t}-1}+ \\
& \beta_{2} \mathrm{SI}_{\mathrm{t}-1} *\left(1-\mathrm{D}_{\mathrm{t}-1}\right)
\end{aligned}
$$

Where: $r_{t}$ (IHSG monthly return (percentage)); $r_{f}$ (risk free rate, Bank Indonesia Certificates (SBI)(percentage)); SI (Sentiment Index, Business Tendency Index (ITB) (index)) $\mathrm{D}_{\mathrm{t}-1}$ (dummy variable (nominal)); $\alpha, \beta, \sigma, \gamma$, $\theta, \omega$ (coefficients).
Dummy variable or $\mathrm{D}_{\mathrm{t}-1}$ used in this study is an indicator variable for capturing bullish/optimistic. The value of $\mathrm{D}_{\mathrm{t}-1}$ is one (1) if the previous period's sentiment index is positive. If the value of ITB in the previous period is more than 100 then the Dummy is equal to one (1) and the Dummy value is zero $(0)$ if the previous ITB period is less than 100 .

\section{Descriptive Statistics Test}

Descriptive statistical test was conducted on the data used in this study before classical assumptions tests such as stationarity, autocorrelation, multicolinearity, and heteroscedasticity test are done. Based on Alam et al. (2013) descriptive statistical tests conducted are mean, median, maximum, minimum, and standard deviation.

Data normality can be seen using kurtosis value, skewness value and Jarque-Bera probability. Kurtosis is a measure of data sharpness while skewness is a measure of data slope to average value whether it has a symmetrical shape or not. If the data is more pointy then the data gets collected and the more dull the shape then the data is more spreaded. If Jarque-Bera probability value smaller than the error rate, it indicates that the data has been normally distributed.

\section{Classical Assumption Test}

Stationarity test of data can be done with Augmented Dickey-Fuller (ADF) test. If ADF test statistic value is greater than critical test values means the data does not contain the root unit and is stationary. This test is done to avoid spurious regresion. Autocorrelation means there is correlation between past data and future data in time series (correlation in its self). The autocorrelation test was performed by looking at Durbin Watson statistics. Multicollinearity is a perfect or linear relation between explanatory variables (independent variables). Multicollinearity effects are: high variance and covariance, $t$-ratio that tends to be insignificant but R2 that tends to be high, also high sensitivity. Heteroscedasticity test was done by testing ARCH effect arising from correlation between error or 
disturbance in previous period. The presence of ARCH effects indicates heteroscedasticity.

\section{Best Model Selection}

After model estimation was done, best model selection based on the three criterias which are Akaike Information Criterion (AIC), Schwartz Information Criterion (SIC), and Hannan-Quinn Criterion (HQ). The selected model is the model that has the smallest AIC, SIC and HQ values.

\section{Model Evaluation}

This step was done after choosing the best model, with an aim to know whether the model is able to explain the mean and variance equation well, and whether the model has eliminated ARCH effect contained in the dependent variable. The way to analyze it is by performing residual diagnostic test in the form of ARCH-LM test. The framework of this research is presented in Figure 2.

\section{RESULTS}

The result of descriptive analysis describes the characteristics of time series data from the IHSG return, SBI, and ITB during the study period from January 2001 to December 2015. Characteristics of the data described, among others, were mean, median, maximum, minimum, and standard deviation presented in Table 2.

Based on Table 2 it is known that the average value or mean of IHSG return shows the average return rate obtained by the IHSG that is equal to 1.5591 . The median of IHSG returns, SBI, and ITB are 2.1530; 0.62 ; and 105.96. The positive value of IHSG return median indicates that investors benefited from the returns obtained during the study period. The average value of SBI is 0.7336 while the average value of ITB is 106.0293. It reflects investment return without risk is not too large, while the mean and median of ITB which is above 100 indicates that the average investor sentiment in Indonesia is positive during study period from 2001 to 2015.

The standard deviation value can be used to determine the initial volatility of stock returns. The higher standard deviation value, the return will be more unstable and uncertain. IHSG standard deviation value of 6.2323 while the standard deviation value of SBI and ITB are 0.285 and 4.9255. IHSG largest return value is 20.131 in April 2009 while the smallest return value of IHSG is -31.3115 in October 2008. The smallest value of SBI is 0.32 in February 2012 while ITB is 93.75 in January 2006. The largest value of ITB is 117.25 in October 2004 while SBI is 1.47 in August 2001.

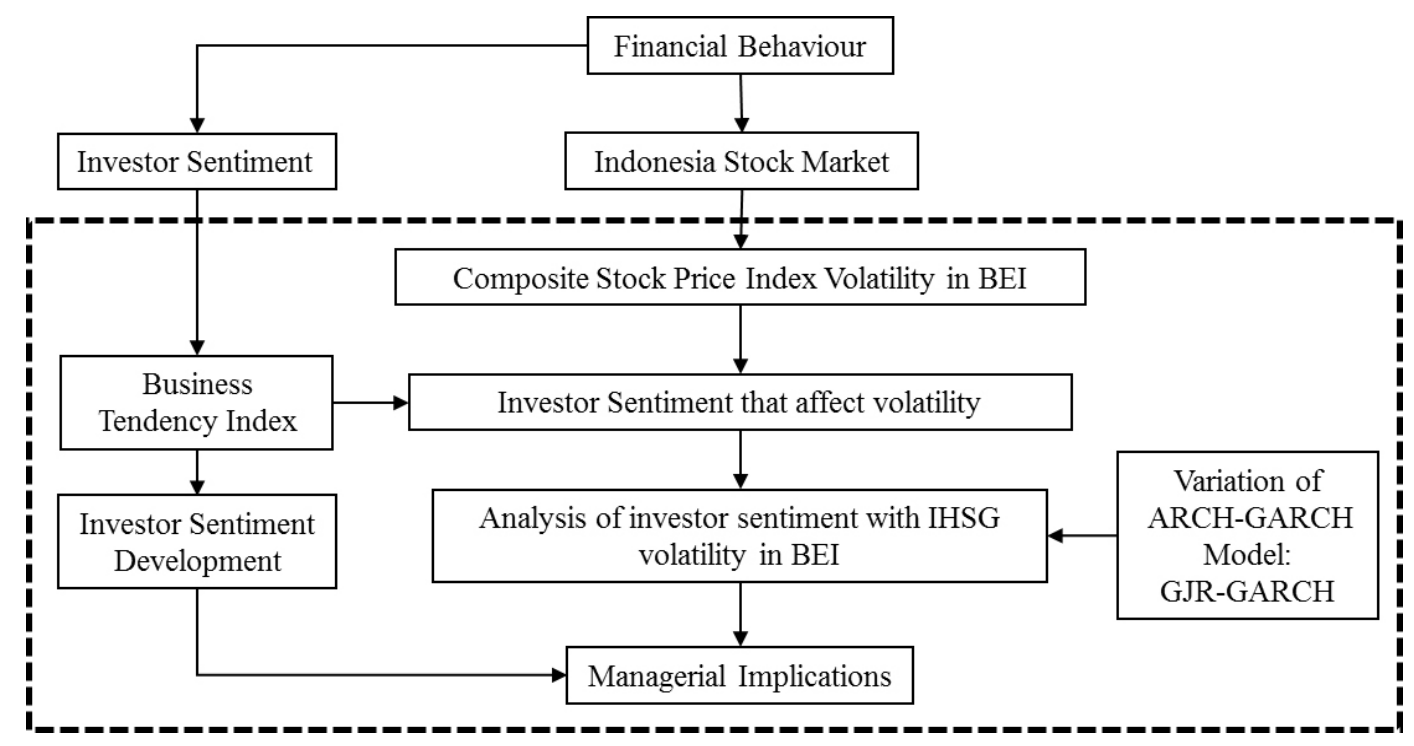

Figure 2. Research framework 
Table 2. Descriptive analysis of IHSG return in BEI, SBI, and ITB

\begin{tabular}{lccc}
\hline DESCRIPTION & IHSG & SBI & ITB \\
\hline Mean & 1.5591 & 0.7336 & 106.0293 \\
Median & 2.1530 & 0.6200 & 105.9600 \\
Maximum & 20.131 & 1.4700 & 117.2500 \\
Minimum & -31.9260 & 0.3200 & 93.7500 \\
Standard Deviation & 6.4998 & 0.2850 & 4.9255 \\
Skewness & -0.7380 & 1.1163 & -0.1688 \\
Kurtosis & 6.2323 & 3.4235 & 2.7042 \\
Jarque-Bera & 0.0000 & 0.0000 & 0.4706 \\
\hline
\end{tabular}

Other way of looking data normality is by value of skewness, kurtosis, and Jarque-Bera probability. The skewness value of IHSG return and ITB are -0.738 and -0.1688 while SBI is 1.1163 . IHSG skewness value is negative or less than zero indicates the left tilt distribution means that data tends to accumulate at high value. This shows that many of IHSG return is positive so that it can provide benefits for investors and investor sentiment is often positive or optimistic. The positive skewness value of SBI or greater than zero represents the right tilt distribution, then it has the right skewed distribution which means the data tends to accumulate at low value. This shows that many SBI values are less than SBI average value which is 0.7336 .

According to Firdaus (2011), if kurtosis value is more than three then data is indicated to have early symptoms of heteroscedasticity. If kurtosis value of return is more than three, this indicates that return tends to accumulate around the mean value and very few returns become different (too high or too low value of returns) that can be used as early identification of heteroscedasticity symptoms. The kurtosis value of IHSG return is 6.2323 indicates there are early symptoms of heteroscedasticity. Jarque-Bera probability value of IHSG return, SBI, and ITB are smaller than the error rate of $5 \%$ so it can be said that the data has been distributed normally.

\section{Classical Assumption Test}

There are four classical assumption tests used to look at what methods can be used in the estimation, so that the estimation results are unbiased (the expected value is not much different or proportional to the true value) and has a low variance. The four tests performed are stationary test, autocorrelation test, multicollinearity test, and heteroscedasticity test with $\mathrm{ARCH}$ effect test. Initial stages taken to avoid the false regression or spurious regression is to test the data of dependent and independent variables with stationary test using Augmented Dickey-Fuller (ADF) test. The ADF test results show that all the dependent and independent variable are stationary at level rate except SBI. The autocorrelation test performed using Durbin-Watson statistic shows that Durbin-Watson value approaching two indicates that there is no autocorrelation among residuals of IHSG return. Multicollinearity test results show the correlation coefficient is smaller than 0.8 so this indicates the absence of multicollinearity problems between variables. Based on the results of heteroscedasticity test, chi-square probability value greater than $5 \%$ of significance level can be said that there is no heteroscedasticity effect on the selected model.

\section{Best Model Selection}

The next step after the classical assumption test is to estimate and select the best model by looking at which model has the smallest AIC, SIC, and HQ values. The model shown in Table 3 is the best model chosen based on the criteria of AIC, SIC, and HQ values. The best GJR-GARCH model in the selected IHSG is the GJRGARCH $(1,1)$ model. Based on the GJR-GARCH model used in study, in the selected IHSG model which is GJR-GARCH $(1,1)$ indicates that the IHSG volatility in a period is affected by the variance in the previous period at $\mathrm{t}-1$ or previous month. In addition, the volatility of IHSG in a period is also affected by the volatility in one previous period at time $\mathrm{t}-1$ or previous month.

The $\alpha 0$ coefficient value at Panel A of -2.63 in Table 3 is the initial constant in the main equation of GJRGARCH IHSG model selected in this study. The coefficient value of $\beta 0$ in Panel B of -88.84 in Table 3 is the initial constant in the variance equation of the selected GJR-GARCH IHSG model.

Results in Panel A in Table 3 have positive and significant $\alpha 2$ values for IHSG returns at $1 \%$ significance levels. If there is $1 \%$ increase in the standard deviation it will increase $0.47 \%$ excess return for that month. This shows that there is a significant influence of investor sentiment in the form of Business Tendency Index to excess return. Positive sentiment prompted investors to be interested in investing which resulted in rising stock demand and stock price increase resulting in an increase in return. At the time of negative sentiment 
occurs investor interest to invest in stocks will decrease so that investors will allocate funds on other types of investment. This caused a decline in stock demand that resulted in falling stock prices and IHSG stock returns. In addition, the effect of Hold More is also seen in the IHSG on the BEI.

The $\alpha 3$ coefficient tests the phenomenon of whether Price Pressure is followed by the Hold More effect. The results showed negative and significant coefficient $\alpha 3$ at $1 \%$. If there is a $1 \%$ increase in the standard deviation it will cause a $0.48 \%$ decrease in excess return in next month. If there is change due to sentiment the investor will be bearish next month. This causes a decrease in the effect of the increase or decrease in stock returns obtained, because there will be a decrease in the amount of increase or decrease in demand and stock prices. Then it can be concluded that at the IHSG in BEI Price Pressure effect is followed by Hold More effect. The results of this study are in line with Sadaqat and Butt (2014) and Tourani-Rad et al. (2008).

The IHSG excess return value in one period is influenced by the regression of excess return of previous period which is indicated by the AR (1) coefficient. With significant AR (1) value of 0.21 at the $5 \%$ significance level indicates that if there is a $1 \%$ increase in the standard deviation in the previous period's excess return regression, the excess return value of this period will increase by 0.21 . The existence of the effect of excess return regression in one previous period is a description of investors who still consider the condition of the previous month in investment activity.

The regression of IHSG excess return in the previous two periods also affected the excess return of IHSG in that period. The AR (2) coefficient value of -0.06 shows that if there is an increase of $1 \%$ in the standard deviation in the excess return regression of the previous two periods, the excess return value of this period will increase by $0.06 \%$. However, the influence of the IHSG excess return regression in the previous two periods was not significant at $1 \%$ significance levels.

Panel B of Table 3 shows the result of conditional volatility. The $\beta 1$ coefficient represents the investor sentiment which is bullish. The positive $\beta 1$ coefficient indicates that when investors are optimistic, indicated by ITB value above 100 , uncertainty in the stock market will increase. When investor sentiment is positive, investor activity in investing will increase, causing uncertainty or volatility of IHSG to increase.

The $\beta 2$ coefficient illustrates the effect of bullish investor behavior. The negative value of $\beta 2$ coefficient indicates that IHSG volatility will increase when the average investor is pessimistic, which is indicated by ITB value below 100. Negative sentiment causes investors to move funds in other types of investment so that IHSG uncertainty or volatility increases. Overall the positive and significant $\mathrm{ARCH}$ and GARCH values at $1 \%$ levels indicate that volatility will persists and the volatility clustering is in accordance with Sadaqat and Butt (2014).

Positive and significant asymmetric coefficient value also can be seen in Table 3. This shows that there is a leverage effect seen when there is a negative shock as ITB value below 100 which will result in a higher change in conditional variance compared to positive shocks at the same magnitude on IHSG. IHSG Investors are more reactive to the shocks due to negative sentiment compared to the shocks caused by positive sentiment. This is why the coefficient value of $\beta 2$ is greater and indicates the effect of asymmetric volatility on IHSG. The results in this study objects null Hypothesis which investor sentiment has significant effect in IHSG volatility.

Table 3. Best GJR-GARCH Model of IHSG in BEI

\begin{tabular}{lc}
\hline Best GJR-GARCH Model & $(1.1)$ \\
\hline Panel A: Mean Equation & \\
$\alpha 0$ & -2.63 \\
$\alpha 1$ & 1.13 \\
$\alpha 2$ & 0.47 \\
$\alpha 3$ & -0.48 \\
AR(1) & 0.21 \\
AR(2) & -0.06 \\
Panel B: Variance Equation & \\
$\beta 0$ & -88.84 \\
$\lambda 1$ & -0.19 \\
$\omega 1$ & 0.18 \\
$\gamma 1$ & 0.98 \\
$\beta 1$ & 0.86 \\
$\beta 2$ & 0.94 \\
Panel C: Diagnostic Test & \\
ARCH & 0.48 \\
\hline
\end{tabular}


The ARCH effect test is performed to see if there are still ARCH effects in the model. At Panel C in Table 3 shows that the ARCH Effect is not present in the best model selected for IHSG. This shows that the best model chosen is a model that can show investor sentiment influence at IHSG in Indonesia Stock Exchange. Given the phenomenon of noise traders in the form of investor sentiment shows that the market is not efficient.

\section{Managerial Implications}

Based on analysis results some formulation of managerial implications can be generated. Parties that can execute this managerial implications are investors and emitent or the company. Some of the managerial implications that can be considered include:

1. For investors, if ITB value is above 100 or there is positive sentiment indicating good news, excess return will increase. Things that can be suggested for investors are if the price is down or investors are advised to immediately make a purchase because of IHSG volatility will go up so investor can gain any benefit. But if the price rises, the investor can make a purchase but the return earned will not be as big as when the price is down or fixed. The same thing happens if there is negative sentiment indicated by ITB value below 100, then IHSG volatility will increase larger but the excess return obtained by investors will decrease. If investors will keep doing the investment activity on the stock then the profit earned will not be as big as good news. Investors can invest in other alternatives such as bonds when there is negative sentiment.

2. For the company, with good news indicated by ITB value above 100 or there is a positive sentiment, it will be able to raise the company's stock price because there will be many requests from investors for the stock. With the increase in stock prices due to the high demand the company can do stock split so that stock prices do not rise too high. If this positive sentiment continues then the company can obtain more funding source from stock sales. However, if there is negative sentiment indicated by ITB value below 100, then the company can buy back the stock because the excess return obtained by the investor is down and the stock will be released by the investor. In addition, the company can also use other funding sources for companies such as bonds or debt.

\section{CONCLUSIONS AND RECOMMENDATIONS}

\section{Conclusions}

The development of Indonesian investor sentiment is done by analyzing at Business Tendency Index or ITB movement. Generally, investor sentiment in Indonesia is positive which can be seen from mean, median and skewness value of ITB that are all above 100. This study of investor sentiment impact on IHSG volatility used Business Tendency Index or ITB as a proxy of investor sentiment. Overall, the results of the research show that investor sentiment is a valuable systematic component in the stock market. This study validates the phenomenon of noise traders which states that the market is inefficient in information and contradicts the classical theory that markets are efficient. The results of this study can be used to increase the predictability of expected stock returns by combining investor sentiment along with other variables such as macroeconomic factors and firm fundamentals.

\section{Recommendations}

Recommendations for investors are investing in stocks when there is positive investor sentiment, and investing in other financial market alternatives when there is negative investor sentiment. For company, when there is a positive investor sentiment the company should do a stock split while there is negative investor sentiment company can buy back and use other funding sources such as bonds. Further research can analyze the influence of investor sentiment impact on the economic sector in Indonesia Stock Exchange or joint stocks such as LQ45 or KOMPAS100. In addition, the use of composite index consisting of internal and external factors such as macroeconomic as a proxy of investor sentiment variable can be done for further research.

\section{REFERENCES}

Alam MZ, Siddiqie, Masukujaman M. 2013. Forecasting volatility of stock indices with arch model. International Journal of Finance Research 4(2): 126-143. https://doi.org/10.5430/ijfr.v4n2p126.

Black F. 1986. Noise. The Journal of Finance. 41(3): 529-543.https://doi.org/10.1111/j.1540- 
6261.1986.tb04513.x.

[BPS] Badan Pusat Statistik. 2013. Indeks Tendensi Bisnis dan Indeks Tendensi Konsumen 2013. Jakarta: Badan Pusat Statistik.

Bollerslev T. 1986. Generalized Autoregressive Conditional Heteroskedasticity. Journal of Econometrics 31(3): 307-27. https://doi. org/10.1016/0304-4076(86)90063-1.

Brown G, Cliff M. 2004. Investor sentiment and the near term stock market. Journal of Empirical Finance 11: 1-27. https://doi.org/10.1016/j. jempfin.2002.12.001.

Calafiore PJ. 2010. Two essays on the impact of rational and irrational investor sentiments on equity market return and volatility: evidence from the u.s. and brazil [disertasi]. Texas: University of Texas-Pan American.

Campbell JY, Kyle AS. 1993. Smart money, noise trading and stock price behaviour. Review of Economic Studies 60(1): 1-34. https://doi. org/10.2307/2297810.

De Long J, Shleifer A, Summers L, Waldmann R. 1990. Noise trader risk in financial market. Journal of Political Economy 98(4): 703-738. https://doi. org/10.1086/261703.

Engle RF. 1982. Autoregressive conditional heteroskedasticity with estimates of the variance of uk inflation. Econometrica 50 (4): 987-1007. https://doi.org/10.2307/1912773.

Firdaus M. 2011. Ekonometrika: Suatu Pendekatan Aplikatif. Jakarta: Bumi Aksara.

Glosten LR, Jaganathan R, Runkle D. 1993. On the relation between the expected value and the volatility of the normal excess return on stocks. Journal of Finance 48: 1779-1801. https://doi. org/10.1111/j.1540-6261.1993.tb05128.x.

Hoque HAAB, Kim JH, Pyun CS. 2007. A comparison of variance ratio tests of random walk: a case of Asian emerging stock markets. International Review of Economics and Finance 16(4): 488502. https://doi.org/10.1016/j.iref.2006.01.001.

Huerta D, Egly PV, Diego EE. 2016. The liquidity crisis, investor sentiment, and reit returns and volatility. Journal of Real Estate Portfolio Management 22(1): 47-62.

Johnk DW. 2012. Essays on time-varying risk and investor sentiment: evidence from the u.s. and g-7 countries using multivariate garch modeling [disertasi]. Texas: University of Texas-Pan
American.

Kencana APP. 2015. Analisis hubungan antara sentimen investor dan return pasar dengan pendekatan mutual fund flow dan analisa vector autoregressive (VAR) [tesis]. Jakarta: Universitas Indonesia.

Kim JH, Shamsuddin A. 2008. Are Asian stock markets efficient? Evidence from new multiple variance ratio tests. Journal of Empirical Finance 15(3): 518-532. https://doi.org/10.1016/j. jempfin.2007.07.001.

Lee WY, Jiang CX, Indro DC. 2002. Stock market volatility, excess returns, and the role of investor sentiment. Journal of Banking dan Finance 26: 2277-2299.

Lovell KS. 2013. The effect of investor sentiment on futures market returns and volatility. [disertasi]. Edinburg: University of Texas-Pan American.

Manurung J, Manurung AH. 2009. Ekonomi Keuangan dan Kebijakan Moneter. Jakarta: Salemba Empat.

Morck R, Shleifer A, Vishny R. 1990. The Stock Market and Investment: Is The Market a SideShow? Brookings Papers on Economic Activity 2: 157-215. https://doi.org/10.2307/2534506.

Puspitaningtyas Z. 2013. Perilaku Investor dalam Pengambilan Keputusan Investasi di Pasar Modal. Conference Paper.

Saad MDP, Siagian H. 2011. Sentimen Investor, Kendala Keuangan, Dan Equity Market Timing. Finance and Banking Journal 13(1): 1-15.

Sadaqat M, Butt HA. 2016. Modelling sentiment, temporal volatility and excess return: empirical evidence from segmented stock market. Journal of Business dan Economics 8(2): 202-228.

Sayim M, Morris PD, Rahman H. 2013. The effect of us individual investor sentiment on industryspecific stock returns and volatility. Review of Behavioral Finance 5(1): 58-76. https://doi. org/10.1108/RBF-01-2013-0006.

Sayim M. 2012. The Role Of Investor Sentiments on Stock Market Returns and Volatility: Evidence From Turkey and The U.S. [disertasi]. San Diego: School of Management Alliant International University.

Thaler RH. 1999. Mental accounting matters. Journal of Behavioural Decision Making 12(3): 183-206. https://doi.org/10.1002/ (SICI)1099-0771(199909)12:3<183::AID- 
BDM318>3.0.CO;2-F.

Tourani-Rad A, Beaumont R, Daele M, Frijns B, Lehnert T, Muller A. 2008. Investor sentiment, mutual fund flows and its impact on returns and volatility. Managerial Finance 34 (11): 772-785. https://doi.org/10.1108/03074350810900505.

Uygur U, Tas O. 2014. The impacts of investor sentiment on different economic sectors: evidence from istanbul stock exchange. Borsa Istanbul Review 48(3): 1165-1179. https://doi.org/10.1016/j. bir.2014.08.001.
Verma R, Verma P. 2006. Noise Trading and Stock Market Volatility. Journal of Multinational Financial Management 17(3): 231-243. https:// doi.org/10.1016/j.mulfin.2006.10.003.

Yu J, Huang HH, Hsu SW. 2014. Investor Sentiment Influence on The Risk-Reward Relation in The Taiwan Stock Market. Emerging Markets Finance and Trade 50 (Supp1.2): 174-188. https:/doi. org/10.2753/REE1540-496X5002S212. 